NBER WORKING PAPER SERIES

\title{
THE MICROECONOMIC EVIDENCE ON CAPITAL CONTROLS: NO FREE LUNCH
}

\author{
Kristin J. Forbes
}

Working Paper 11372

http://www.nber.org/papers/w11372

\author{
NATIONAL BUREAU OF ECONOMIC RESEARCH \\ 1050 Massachusetts Avenue \\ Cambridge, MA 02138
}

May 2005

Paper prepared for NBER Conference on International Capital Flows held in Santa Barbara, California on 12/16-12/18. Thanks to Charles Calomiris and participants in the NBER conference for helpful comments and suggestions. Further thanks to Peter Kenen for inspiring the title of this paper. Author contact information: MIT-Sloan School of Management, 50 Memorial Drive, Room E52-455, Cambridge, MA 02142; kjforbes@mit.edu; http://web.mit.edu/kjforbes/www The views expressed herein are those of the author(s) and do not necessarily reflect the views of the National Bureau of Economic Research.

(C2005 by Kristin J. Forbes. All rights reserved. Short sections of text, not to exceed two paragraphs, may be quoted without explicit permission provided that full credit, including $\odot$ notice, is given to the source. 
The Microeconomic Evidence on Capital Controls: No Free Lunch

Kristin J. Forbes

NBER Working Paper No. 11372

May 2005

JEL No. F2, F3, G1

\begin{abstract}
$\underline{\text { ABSTRACT }}$
Macroeconomic analyses of capital controls face a number of imposing challenges and have yielded mixed results to date. This paper takes a different approach and surveys an emerging literature that evaluates various microeconomic effects of capital controls and capital account liberalization. Several key themes emerge. First, capital controls tend to reduce the supply of capital, raise the cost of financing, and increase financial constraints - especially for smaller firms, firms without access to international capital markets and firms without access to preferential lending. Second, capital controls can reduce market discipline in financial markets and the government, leading to a more inefficient allocation of capital and resources. Third, capital controls significantly distort decisionmaking by firms and individuals, as they attempt to minimize the costs of the controls or even evade them outright. Fourth, the effects of capital controls can vary across different types of firms and countries, reflecting different pre-existing economic distortions. Finally, capital controls can be difficult and costly to enforce, even in countries with sound institutions and low levels of corruption. This microeconomic evidence on capital controls suggests that they have pervasive effects and often generate unexpected costs. Capital controls are no free lunch.

Kristin J. Forbes

MIT Sloan School,Room E52-455

50 Memorial Drive

Cambridge, MA 02142

and NBER

kjforbes@mit.edu
\end{abstract}




\section{Introduction}

The free movement of capital can have widespread benefits. Capital inflows can provide financing for high-return investment, thereby raising growth rates. Capital inflowsespecially in the form of direct investment—often bring improved technology, management techniques, and access to international networks, all of which further raise productivity and growth. Capital outflows can allow domestic citizens and companies to earn higher returns and better diversify risk, thereby reducing volatility in consumption and income. Capital inflows and outflows can increase market discipline, thereby leading to a more efficient allocation of resources and higher productivity growth. In order to obtain these widespread benefits of free capital flows, most developed countries and many developing countries have lifted most of their capital controls.

In the spring of 1997 there was such widespread support for free capital flows that the IMF Interim Committee suggested amending the IMF's Articles of Agreement to extend its jurisdiction to include capital movements and make capital account liberalization a purpose of the IMF. ${ }^{1}$ Soon after this recommendation was announced, however, a series of financial crises spread across Asia and disproportionately affected countries that had recently liberalized their capital accounts. In contrast, several Asian countries that had maintained more stringent capital controls_-such as China and India-emerged from the crisis relatively unscathed. These experiences caused a reassessment of the desirability of capital controls, especially for emerging markets and developing economies.

In a sharp sea change, many policymakers and leading economists now support the use of capital controls, especially taxes on capital inflows, in some circumstances. For example, former U.S. Treasury Secretary Robert Rubin, who actively encouraged emerging markets to open their capital accounts in the mid-1990's, has expressed support for controls on capital inflows. ${ }^{2}$ A series of reports by the G-22 in 1998 raised concerns

\footnotetext{
${ }^{1}$ The IMF's charter requires that member countries have convertible currencies for the purposes of current account transactions, but not capital account transactions.

${ }^{2}$ For example, see Rubin and Weisberg (2003), pg. 257.
} 
about capital account liberalization and cautiously endorsed taxes on capital inflows. ${ }^{3}$ Even the Economist magazine, traditionally a supporter of the free movement of goods and capital, wrote: “...some kinds of restriction on inflows (not outflows) of capital will make sense for many developing countries...Chile’s well-known system...was a success worth emulating.” ${ }^{4}$ Possibly even more surprising, senior officials from the IMF, formerly the bastion of capital market liberalization, have expressed support for taxes on capital inflows. For example, Stanley Fischer, former First Deputy Managing Director of the IMF stated: “The IMF has cautiously supported the use of market-based capital inflow controls, Chilean style."5

One of the most common justifications for this sea change in attitudes and recent support for capital controls is the lack of empirical evidence on the benefits of capital account liberalization. If lifting capital controls does yield net benefits, then these benefits should be measurable and identifiable in empirical analysis. Although an extensive literature has attempted to measure the macroeconomic effects of capital account liberalization, this literature is generally interpreted as being inconclusive. For example, a recent survey of the empirical literature on capital controls by authors in the IMF research department concludes: “...if financial integration has a positive effect on growth, there is as yet no clear and robust empirical proof that the effect is quantitatively significant”. 6 Similarly, Eichengreen (2001) writes: "Capital account liberalization, it is fair to say, remains one of the most controversial and least understood policies of our day...Empirical analysis has failed to yield conclusive results.”

This interpretation that the empirical evidence on capital controls is inconclusive, however, overlooks a number of recent studies using microeconomic data. These studies provide persuasive evidence on the different effects of capital controls and capital account liberalization. The studies cover a variety of countries and periods, use a range of

\footnotetext{
${ }^{3}$ See Group of Twenty-Two reports released in 1988: Report of the Working Group on Transparency and Accountability, Report of the Working Group on Strengthening Financial Systems, and Report of the Working Group on International Financial Crises.

${ }^{4}$ Economist (2003).

${ }^{5}$ Fischer (2001).

${ }^{6}$ Prasad, Rogoff, Wei and Kose (2003).
} 
approaches and methodologies, and build on several different literatures. By focusing on individual experiences and/or specific effects of capital controls, this microeconomic approach can yield more concrete and robust evidence than the cross-country macroeconomic studies that assume capital controls have similar effects across countries and periods. Granted, this microeconomic approach has the disadvantage that it is difficult to generalize from individual country experiences. It also has the disadvantage that it is difficult to aggregate the different microeconomic results to capture the macroeconomic effects of capital controls. Nonetheless, this new series of microeconomic studies provides compelling and robust evidence of the pervasive effects of capital controls.

This paper surveys these diverse microeconomic studies and attempts to develop a more coherent picture of the microeconomic evidence on capital controls. Several key themes emerge. First, capital controls tend to reduce the supply of capital, raise the cost of financing, and increase financial constraints - especially for smaller firms and firms without access to international capital markets. Second, capital controls can reduce market discipline in financial markets and the government, leading to a more inefficient allocation of capital and resources. Third, capital controls significantly distort decisionmaking by firms and individuals as they attempt to minimize the costs of the controls, or even evade them outright. Fourth, the effects of capital controls can vary across different types of firms and countries, reflecting different pre-existing economic distortions. Finally, capital controls can be difficult and costly to enforce, even in countries with sound institutions and low levels of corruption.

Although this literature examining the microeconomic effects of capital controls is only in its infancy and much more careful analysis remains to be done, the combination of results is compelling. These papers use diverse methodologies to examine very different aspects of capital controls in a range of countries and time periods, yet most find a consistent result; capital controls have pervasive effects, yield many unexpected costs, and can distort the allocation of resources, all of which can hinder market efficiency. Granted, capital controls may also have some costs and benefits that are not addressed in 
these microeconomic papers_-such as reducing a country's vulnerability to currency crises. ${ }^{7}$ Moreover, in the presence of existing market distortions, capital controls can be a "second-best" policy. ${ }^{8}$ Therefore, this survey is not, in any way, a full cost-benefit analysis of capital controls. Countries evaluating whether to impose capital controls or liberalize their capital accounts need to consider factors other than this microeconomic evidence. The results in this paper do clearly suggest, however, that capital controls (including taxes on capital inflows) create substantial microeconomic distortions. The recent sea change in views supporting capital controls (and bolstered by the inconclusive macroeconomic evidence) appears to be premature. The microeconomic evidence on capital controls presents a clear picture; capital controls have pervasive effects and can generate substantial, unexpected costs. Capital controls are no free lunch.

The remainder of this paper is as follows. Section II discusses reasons why the macroeconomic evidence on capital controls has been inconclusive, to date. Section III surveys the microeconomic evidence on how capital controls affect the supply and cost of capital. Section IV reviews the evidence on how controls affect market discipline and the allocation of capital. Section V describes how controls can affect the behavior and actions of firms and individuals. Section VI briefly discusses the challenges to implementing and enforcing capital controls. Section VII concludes.

\section{Inconclusive Macroeconomic Evidence on Capital Controls}

The macroeconomic literature has had limited empirical success, to date, in providing robust evidence on the benefits of capital account liberalization. ${ }^{9}$ Most papers in this literature use a variant of the standard cross-country growth regression developed by Robert Barro to test if the presence of capital controls or capital account liberalization is correlated with higher economic growth. Prasad et al. (2003) provide a detailed survey of this literature and argue that the results are inconclusive. More specifically, of the 14

\footnotetext{
${ }^{7}$ See Block and Forbes (2004) for an evaluation of the various costs and benefits of capital controls.

${ }^{8}$ For example, if capital market inefficiencies allow companies to overborrow, capital controls that limit the supply of loans may minimize the initial distortion.

${ }^{9}$ For excellent surveys of this literature, see Edison, Klein, Ricci and Sloek (2002), Eichengreen (2001), or Prasad et al. (2003).
} 
recent papers they examine, three find a positive effect of financial integration on growth, four find no effect, and seven find mixed results. The only consistency in the papers surveyed is that none find evidence that capital account liberalization significantly reduces growth. Prasad et al. (2003) also perform their own analysis, with the key result replicated in Figure 1. They find no significant relationship between financial openness and the growth in real per capita income across countries-even after controlling for standard variables in this literature. ${ }^{10}$

There are several possible explanations for these conflicting results and lack of consensus in the macroeconomic literature. ${ }^{11}$ First, it is extremely difficult to accurately measure capital account openness. ${ }^{12}$ Many studies use rough numerical indices of different policies and regulations, but even the more carefully constructed measures cannot capture the complexity and effectiveness of a country's liberalization. Due to these problems, other studies have used de facto measures of integration (such as capital flows or foreign asset holdings). These are also problematic since some countries with large capital inflows still maintain relatively strict capital controls (such as China), while other countries with relatively unrestricted capital accounts receive little foreign capital (such as many African nations). Still other studies have examined market comovement to measure integration with international markets, but these studies face the challenge of controlling for other factors that could cause markets to commove-such as global shocks or similar asset structures. A final approach has been to study onshore-offshore interest rate differentials. This approach is also problematic since not only are these differentials only available for a limited set of countries, but also interest rate differentials could move due to a number of factors other than capital account liberalization.

Second, different types of capital flows and capital controls may have different effects on growth and other macroeconomic variables. For example, recent work suggests that the

\footnotetext{
${ }^{10}$ The control variables include: initial income, initial schooling, average investment/GDP, political instability, and regional dummies.

${ }^{11}$ For a more thorough discussion of these challenges, see Eichengreen (2003), Chapter 3, Prasad et al. (2003), or Magud and Reinhart (2004).

${ }^{12}$ See Edison, Klein, Ricci and Sloek (2002) for an excellent discussion of different measures of capital account openness.
} 
benefits of foreign direct investment may be greater than that of other types of capital flows. Reisen and Soto (2001) examine the impact of six different types of capital flows on growth and find that only two-FDI and portfolio equity flows-are positively associated with growth. Henry and Lorentzen (2003) argue that equity market liberalizations are more likely to promote growth than debt market liberalizations. Other papers argue that controls on capital inflows may be less harmful than controls on capital outflows, because controls on inflows may be viewed as a form of prudential regulation, while controls on outflows may be viewed as a lack of government commitment to sound policies. For example, Rossi (1999) finds that controls on capital inflows reduce the risk of a currency crisis, while controls on capital outflows heighten the risk. Moreover, even the sequence in which different types of capital controls are removed may determine the aggregate impact. For example, lifting restrictions on offshore bank borrowing before freeing other sectors of the capital account may increase the vulnerability of a country's banking system (as seen in Korea in the mid-1990’s).

Finally, the impact of removing capital controls could depend on a range of other, hardto-measure factors that are difficult to capture in simple cross-country regressions, such as a country's institutions or corporate governance. For example, Chinn and Ito (2002) show that financial systems with a higher degree of legal and institutional development benefit more, on average, from liberalization. ${ }^{13}$ Gelos and Wei (2002) show that countries with greater transparency are not only more likely to attract international equity investment, but are less vulnerable to herding and capital flight during crises. Closely related, there may be "threshold effects" that are difficult to capture in linear regressions. More specifically, countries may need to attain a certain level of financial market integration or overall economic development before attaining substantial benefits from lifting capital controls. For example, Klein and Olivei (1999) find that capital account openness only stimulates financial development in OECD countries. Moreover, most countries that remove their capital controls simultaneously undertake a range of additional reforms and undergo widespread structural changes. Therefore, it can be

\footnotetext{
${ }^{13}$ Aghion, Bacchetta, and Banerjee (2001) develop a theoretical model of why financial development is a key variable determining the impact of capital account liberalization.
} 
extremely difficult to isolate the specific impact of removing capital controls during these transition periods.

Given all of these challenges to measuring the impact of capital controls, it is not surprising that the empirical literature has had difficulty documenting the effect of capital controls on growth at the macroeconomic level. Moreover, to put these challenges in perspective, the current status of this literature is similar to the earlier literature on how trade liberalization affects growth. Economists generally believe that trade openness raises economic growth, but most of the initial work on this topic (which used the same cross-country framework as these studies of capital account openness) also reached inconclusive results. In some cases trade liberalization appeared to have a positive correlation with economic growth, but in most cases these results were not robust to sensitivity testing. Stanley Fischer recently made this point: "With regard to empirical evidence on the benefits of capital account liberalization, I believe we are roughly now where we were in the 1980's on current account liberalization — that some evidence is coming in, but that it is at this stage weak and disputed. ${ }^{14}$ Since accurately measuring capital account liberalization and its interactions with other key variables may be even more difficult than for trade liberalization, it is not surprising that the initial work in this area has generated mixed results to date.

Although the macroeconomic empirical evidence on how trade openness affects growth took years to develop, at a much earlier date several papers using microeconomic data and case studies found compelling evidence that trade liberalization raises productivity and growth. Similarly, recent work using microeconomic and case-study evidence has been much more successful than the macroeconomic literature in documenting the costs of capital controls. Although case studies have shortcomings, such as the difficulty controlling for other simultaneous events and generalizing to different countries and experiences, this microeconomic approach can avoid many of the problems with the macroeconomic, cross-country literature. Moreover, this microeconomic approach can

\footnotetext{
${ }^{14}$ Fischer (2003), pg. 14.
} 
facilitate a much more detailed measurement of exactly how capital account liberalization affects the allocation of resources and market efficiency.

\section{Capital Controls and the Supply and Cost of Capital}

Lifting capital controls should allow capital to flow where it can earn the highest expected rate of return. Since capital is relatively scarce in low-income, labor-intensive economies, the return to capital would be expected to be higher, on average, than in capital-abundant, wealthy countries. Therefore, standard economic theory suggests that when emerging markets lift their capital controls, capital should tend to flow in from wealthier countries. Capital inflows could generate substantial benefits, such as providing capital for investment, making advanced technology available, and spurring competitiveness.

This simple prediction, however, does not hold for many countries. Most capital currently flows from developing to developed countries or between developed countries—not from developed to developing countries. Figure 2 shows that emerging markets have been net exporters of capital, instead of net importers, since 2000. Even before 2000 when emerging markets were net capital importers, their volume of capital inflows was much lower than might be expected given their relative scarcity of capital. One reason why capital inflows to developing countries may be so low is the greater prevalence of capital controls in these markets. Some low- and middle- income countries that have lifted their capital controls, however, still experience net capital outflows.

There are a number of reasons why capital might flow from capital-scarce to capital-rich countries, even in the absence of capital controls. First, the enforceability of property rights is weak in most developing countries. Second, informal administrative barriers, (such as corruption, the absence of transparent rules for investment, and the scarcity of trained, professional civil servants) can discourage foreign investment in developing countries. Third, lower levels of human capital in developing countries can reduce 
productivity. ${ }^{15}$ Finally, many developing countries have a history of default and substantially higher credit risk. ${ }^{16}$ All of these factors can reduce the expected return to capital in developing countries, despite their relative scarcity of capital. For all of these reasons, if emerging markets lift their capital controls, capital could actually flow out, instead of into the country. As a result, it is difficult to predict, a priori, how lifting capital controls will affect the supply of capital in a country.

Moreover, lifting capital controls can affect the cost of capital not only by affecting the supply of capital, but also by allowing investors to expand their portfolio of asset holdings to better diversify risk. Since asset returns in an individual country are not perfectly correlated with global asset returns (or returns in any other individual country), removing capital controls can facilitate international risk sharing. A greater diversification of risk will reduce the volatility of expected portfolio returns, thereby reducing the cost of capital. ${ }^{17}$

\section{A. The Cross-country Evidence}

Several microeconomic studies address these issues by assessing how lifting capital controls affects equity markets, the cost of capital, and financial constraints for different types of firms. Chari and Henry (2004b) examines the impact of removing controls on stock market investment on different types of firms in 11 emerging markets. It finds that when publicly-listed firms become eligible for foreign ownership, they experience an average stock price revaluation of $15.1 \%$ and a significant fall in their average cost of capital (with the risk-free rate of return falling between $5.9 \%$ and $9.1 \%$, depending on the specification).$^{18}$ The impact on the expected returns of individual firms is directly proportional to the firm-specific changes in systematic risk resulting from the liberalization. These affects are also greater for stocks which become "investible" (i.e., which can by purchased by foreigners after liberalization) as compared to firms which are

\footnotetext{
${ }^{15}$ See Lucas (1990).

${ }^{16}$ Reinhart and Rogoff (2004).

${ }^{17}$ See Bekaert and Harvey (2003) for a formal model and more detailed discussion of this effect.

${ }^{18}$ These results are supported by several macroeconomic studies of how liberalizations affect equity markets. For example, Henry (2000) shows that the mean growth rate of private investment increases by about 22 percentage points over the 3 years after liberalizations in emerging markets. Bekaert and Harvey (2000) shows that the cost of capital decreases by between 5 and 75 basis points after liberalizations.
} 
"noninvestible" (i.e., remain off-limits for foreign investment). These results suggest that the supply of capital increases and the cost of capital decreases after removing capital controls on equity investment, although the effects will vary across different types of firms.

A number of studies assess the impact of removing capital controls on the supply and cost of capital by using a different approach-measuring how capital controls affect the financing constraints of different types of companies. Financing constraints are generally measured as the sensitivity of investment to cash flow, while controlling for a number of firm-level variables (including investment opportunities). Harrison, Love and McMillan (2004) follows this approach and uses an extensive cross-country, time-series, firm-level data set. ${ }^{19}$ The study finds that restrictions on capital account transactions tend to increase firms' financing constraints. These financial constraints are greater for firms that are domestically-owned (as compared to those with either foreign ownership or assets), which the authors interpret as being "consistent with the hypothesis that foreign investment is associated with a greater reduction in the credit constraints of firms which are less likely to have access to international capital markets. ${ }^{20}$ Restrictions on capital flows other than capital account transactions - such as on import surcharges or surrender requirements for exporters- have no impact on firms' financial constraints. The study also finds that increased foreign direct investment (FDI) is associated with reduced firm financing constraints-although a number of factors other than lifting controls on capital inflows will determine FDI flows.

Several studies use broader measures of liberalization and also find that greater liberalization decreases financial constraints in a panel of firms and countries. One of the most common measures of liberalization is financial liberalization — which generally includes lifting controls on foreign investment in the financial sector, as well as lifting controls on interest rates and reducing directed-credit programs. For example, Laeven

\footnotetext{
${ }^{19}$ Capital controls are measured using different dummy variables for the five categories of capital controls in the IMF's Trade and Exchange Restrictions. This measure of capital controls is imprecise and its problems are discussed in the literature surveyed in Section II.

${ }^{20}$ Harrison, Love and McMillan (2004), pg. 272.
} 
(2003) constructs a new measure of banking sector liberalization that includes several factors in addition to removing barriers to bank entry by foreign investors. Using this measure, the study finds that financial liberalization significantly reduces financing constraints for small firms, with an 80 percent average reduction in the sensitivity of investment to cash flow. Laeven (2003) also finds that large firms tend to be less financially constrained before liberalization and are less likely to experience a reduction in financial constraints afterward. There is even some evidence that large firms may experience an increase in financial constraints after bank liberalizations. The study suggests this may reflect that "in many developing countries, large firms had access to preferential (directed) credit during the period before financial liberalization. This form of favoritism is likely to decrease during financial liberalization.”21

Other papers expand beyond the banking sector and use even broader measures of financial liberalization to examine the microeconomic impact on firm-financing constraints. ${ }^{22}$ For example, Love (2003) uses an index of financial development that includes market capitalization, value traded, and the share of credit going to the private sector. Although this study does not explicitly test the relationship between this measure of financial development and capital account liberalization, other work shows that capital account liberalization tends to significantly increase financial market development. ${ }^{23}$ Love (2003) finds a strong negative relationship between financial market development and financing constraints for all types of firms. It also finds that smaller firms have significantly greater financial constraints than larger firms in less financially developed countries.

\section{B. Evidence from Individual Countries}

This series of studies using a range of different statistics to measure capital account liberalization and its impact on firm-financing constraints has utilized cross-country, firm-level data. Although cross-country data has the obvious advantage of being able to

\footnotetext{
${ }^{21}$ Laeven (2003), pg. 25.

${ }^{22}$ Closely related, Demirguc-Kunt and Maksimovic (1998) show that firms in countries with a more active stock market and large banking sector grow faster than they could using only internally-generated funds.

${ }^{23}$ For example, see Klein and Olivei (1999). Also see Bekaert and Harvey (2003) for an excellent survey of this literature.
} 
test for common relationships across different countries, it has the disadvantage of aggregating across very different liberalization experiences and relying on more limited data that is only available across countries. In order to avoid these problems, several studies have focused on individual country experiences with capital account liberalization and firm-financing constraints.

One country that has received substantial attention is Chile. Chile enacted taxes on capital inflows (the encaje) from 1991 to 1998. This experience is useful for case studies not only because it is generally cited as one of the most successful examples of capital controls, but also since the enactment and then removal of the tax provides a useful timeseries dimension to assess its impact. ${ }^{24}$ Forbes (2003) examines how the encaje affected investment and financial constraints for different types of publicly-traded firms in Chile. Figure 3, which is replicated from the paper, shows that investment growth was higher for smaller, publicly-traded firms than larger firms both before and after the encaje (which is a standard result in the finance literature). During the period that the capital controls were in place, however, investment growth plummeted for smaller companies and was generally lower than for larger companies. A more formal empirical analysis in the study that controls for a range of variables confirms these results and indicates that the encaje significantly increased financial constraints for smaller, publicly-traded companies, but not for larger firms.

Gallego and Hernández (2003) uses a different estimation technique to examine the impact of capital controls in Chile, but finds similar results. This study shows that the encaje significantly increased the cost of external funding for Chilean firms, although the average effect was small in magnitude. These effects also vary substantially across different types of firms. For example, the impact of the encaje on financing costs for smaller firms was about 60 basis points higher than for firms that could issue securities abroad. Gallego and Hernández (2003) also examines the impact of lifting restrictions on capital outflows in Chile. In contrast to the effect of the encaje, lifting controls on capital

\footnotetext{
${ }^{24}$ See Forbes (2003) for more information on the encaje and the literature assessing the impact of these capital controls.
} 
outflows increases the cost of funding for all types of firms, although the magnitude of the effect is small. The paper states that controls on capital outflows by "keeping national savings 'captive' in the local market may have resulted in an artificially lower cost of borrowing for firms." 25

Although most other countries do not provide as clear a natural experiment to test the impact of capital account liberalization as the Chilean encaje, other studies have focused on how broader measures of financial liberalization affect firm-financing constraints. For example, Gelos and Werner (2001) examines the impact of widespread financial market liberalization in Mexico in the late 1980's on fixed investment in Mexican manufacturing firms. ${ }^{26}$ The study finds that after financial market liberalization, financial constraints were significantly eased for smaller companies, although not larger companies. Liberalization may not have reduced financial constraints for larger companies for two reasons. First, larger companies had much lower financial constraints before liberalization. Second, larger companies were more likely to have stronger political connections that provided better access to directed credit at preferential rates before liberalization.

Other studies examine the impact of broader financial market liberalizations in other Latin American countries. Gallego and Loayza (2000) focuses on Chilean firms between 1985 and 1995 and finds that firms were financially constrained before liberalization (during the period from 1985 to 1990), and these constraints were significantly reduced after liberalization (from 1991 to 1996). The paper does not test for the impact of the encaje (which was enacted mid-way through the later period), or differentiate between large and small firms. ${ }^{27}$ Jaramillo, Schiantarelli, and Weiss (1996) focuses on Ecuadorian firms in the 1980s and finds that capital market imperfections caused smaller and younger firms to be more financially constrained than older firms. Financial constraints

\footnotetext{
${ }^{25}$ Gallego and Hernandez (2003), pg. 243.

${ }^{26}$ This study uses an innovative approach to address a censoring problem in investment data by using real estate as a collateral.

${ }^{27}$ Gallego and Loayza (2000) find evidence, however, that firms eligible for investment in pension funds (PFMC-grade firms) were less financially constrained than non PFMC-grade firms before 1990. Since PFMC-grade firms tend to be larger than the average Chilean firm, this is consistent with they hypothesis that smaller firms were more financially constrained than larger firms during this period.
} 
do not fall significantly after liberalization (even for small firms), but the authors admit that since financial reform was an ongoing process, it is difficult to clearly identify the “pre” and "post” reform episodes. They also admit that this time-series analysis is complicated by several macroeconomic events during this period, including severe inflation in 1988, a major earthquake, loose fiscal policy, and a sharp reduction in credit provided by the central bank.

A final country study of the impact of financial market liberalization on financial constraints is Harris, Schiantarelli, and Siregar (1994). This study examines Indonesian manufacturing establishments and suffers from similar time-series identification problems as Jaramillo, Schiantarelli and Weiss (1996). With this caveat, the study finds that liberalization improves access to financing for all types of firms, but may increase borrowing costs, especially for smaller firms. The study suggests that the movement from preferential credit to lending based on market mechanisms can increase the overall availability of financing, but may simultaneously raise the cost of capital for individual firms that previously benefited from preferential access to credit.

\section{Summary}

This series of cross-country and individual case studies on the impact of capital controls, capital account liberalization, and broader financial market liberalization on the supply and cost of capital has several key themes. First, liberalization tends to reduce the cost of capital and ameliorate financial constraints, on average, two effects that are consistent with liberalizations increasing the supply of capital. Second, smaller firms and companies that did not previously have access to international capital markets are more likely to experience these benefits of liberalizations. Third, certain types of firms in several countries may have benefited from capital controls and more restricted financial markets, possibly through preferential lending agreements. These companies were less likely to benefit from reduced financial constraints after liberalizations, and may even face a higher cost of capital. This set of microeconomic results clearly suggests that capital controls can reduce the supply and increase the price of capital, making it more difficult for many firms to obtain financing for productive investment. Although experiences vary 
across countries, these effects are generally greatest for smaller firms, firms in less distorted financial markets, and firms without access to international capital markets or preferential lending arrangements. This impact of capital controls on small firms could be particularly important for emerging markets in which small and new firms are often important sources of job creation and economic growth.

\section{Capital Controls and Market Discipline}

Capital controls can not only reduce the supply and increase the cost of capital, but they can insulate an economy from competitive forces, reducing market discipline and allowing capital to be allocated inefficiently. Some of the results discussed in the last section were consistent with this effect-although none of the studies tested it explicitly. An additional series of microeconomic papers, however, tests whether capital controls affect market discipline through three closely related channels: through the efficiency with which capital is allocated, through the government's ability to channel resources inefficiently, and through the information content in asset prices.

\section{A. Capital Controls and the Allocation of Capital}

Chari and Henry (2004a) is the most careful study directly testing for the impact of capital controls on the allocation of capital. This study examines how stock market liberalizations in emerging markets affect investment and the return to capital for different types of firms. It finds that firms with better fundamentals before liberalization have a greater increase in capital investment after liberalization. Moreover, this effect of firm characteristics on the allocation of investment can outweigh the average effects on all equities from liberalization. For example, the paper's baseline estimates show that a 1 percentage point increase in a firm's expected future cash flow (indicating stronger fundamentals) predicts a 4.1 percentage point increase in its investment ratio after liberalization. In comparison, the country-specific impact of liberalization on the cost of capital only predicts a 2.3 percentage point increase in investment. The authors conclude that stock market liberalizations do "not constitute a wasteful binge" and that the 
"invisible hand" is "discerning” in its ability to allocate capital to firms with higher expected returns after liberalizations.

A number of studies focus on how liberalizations in areas other than equity markets affect the allocation of investment across firms. Galindo, Schiantarelli, and Weiss (2003) assesses if banking sector liberalizations (which include reducing barriers to foreign investment as well as other reforms) improve the efficiency with which investment is allocated in 12 developing countries. The study measures the efficiency of the allocation of capital using an index measuring if investment funds go to firms with a higher marginal return to capital. The return to capital is measured using panel estimates of a Cobb-Douglas production function. Results show that liberalizations increase the efficiency of the allocation of investment in the majority of emerging markets in their sample. Jaramillo, Schiantarelli, and Weiss (1992) focuses on a broader definition of financial market liberalization (including the banking sector as well as other financial markets) and only include firms in Ecuador during its period of liberalization in the 1980's. They also find that liberalization increases credit flows to more "technically efficient” firms, although the time-series framework in this study has several problems (as discussed in Section III.B).

Several microeconomic studies have also tested for a relationship between the allocation of capital and overall financial development, as measured by the size of a country's equity and credit markets relative to GDP. This measure has a positive, although even weaker relationship to capital controls than measures of financial market liberalizations (as discussed above). Nonetheless, the results from these studies are consistent with the results on how capital controls affect the allocation of capital. For example, Wurgler (2000) uses industry-level data to show that investment growth is more closely associated with the growth in value-added (a measure of the return to capital) in countries with more developed financial systems. Rajan and Zingales (1998) shows that industries that are more reliant on external financing grow faster in more financially developed countries, 
suggesting that financial development reduces firms' costs of external finance. ${ }^{28}$ These results suggest that capital is allocated more efficiently in countries with more developed or deeper financial markets.

Abiad, Oomes and Ueda (2004) also examines the relationship between financial markets and the allocation of capital, but explicitly tests for differences in the relative importance of financial liberalization (the focus of the papers at the beginning of this section) and of overall financial development (the focus of the papers in the above paragraph). This study also develops a new method for measuring the efficiency of the allocation of capital. More specifically, it uses the dispersion in Tobin's Q in a given country and year (after controlling for other factors) to proxy for the variation in expected returns. A lower variation in returns is interpreted as indicating that capital is allocated more efficiently, because if a country removes its capital controls, then credit should be reallocated from firms with lower expected returns to firms with higher expected returns, thereby raising expected returns for the former group and reducing them for the later. The study finds that financial liberalization (which includes entry barriers for banks, restrictions on international financial transactions, credit and interest rate controls, privatization and other regulations) improves the allocation of credit across firms. In contrast, financial deepening (which is measured by the volume of credit being intermediated in financial markets) affects firms' access to finance but is a less important determinant of the allocation of capital.

\section{B. Capital Controls and Government's Allocation of Resources}

In developed countries, the allocation of capital and investment is largely determined by financial markets. In emerging markets and developing countries, however, the government often plays a more important role. Moreover, capital controls can insulate governments from market discipline, giving government agencies greater freedom to allocate capital based on factors other than the expected returns to investment. Therefore, instead of testing for the general impact of capital account liberalization on the allocation

\footnotetext{
${ }^{28}$ Reliance on external financing is measured by the industries' reliance on external financing in the United States.
} 
of a capital, an alternate approach is to test if liberalization affects the government's ability to allocate capital to preferred companies.

One paper that uses this approach is Johnson and Mitton (2002). This study examines how the Asian crisis and the announcement of Malaysia's capital controls affected stock returns for individual Malaysian companies. It splits the sample into firms with political connections to senior government officials (such as Prime Minister Mahatir), and those without political connections. The paper finds that in the initial phase of the crisis (before the capital controls were enacted), politically-connected firms experienced a greater loss in market value than firms without political connections. When the controls were put into place, politically-connected firms experienced a relatively greater increase in market value. These results suggest that the Asian crisis initially increased financial pressures on Malaysian firms, improving market discipline and reducing the expected ability of the government to provide subsidies for favored firms. When the capital controls were put into place, however, investors expected that the Malaysian government would have more freedom to help favored firms, thereby reducing market discipline.

Moreover, the empirical estimates in Johnson and Mitton (2002) suggest that this effect of the Malaysian capital controls on expected market discipline was substantial. In the initial phase of the crisis (from July 1997 to August 1998), politically-connected firms lost about $\$ 5.7$ billion in market value due to the fall in the expected value of their connections. When the controls were enacted in September 1998 (and market values were substantially lower), politically-connected firms gained about $\$ 1.3$ billion in market value due to the increased value of their connections. Another calculation indicates that at the end of September 1998, after the capital controls had reduced market discipline, political connections were worth about $17 \%$ of the total market value for connected firms.

\section{Capital Controls and Asset Market Pricing}

Capital controls can also impact the allocation of capital by affecting the liquidity of asset markets and the efficiency of asset market pricing. Controls on capital inflows can make it more difficult for foreigners to invest in domestic financial markets, therefore reducing 
a valuable source of investment and liquidity. On the other hand, controls on capital outflows could increase liquidity by keeping funds inside the country. Similarly, restrictions on domestic companies' ability to raise financing abroad could foster the development and liquidity of domestic financial markets. Controls on either capital inflows or outflows, however, could reduce competitive pressure and market discipline, thereby reducing the information content of asset prices. This effect could be particularly important in less developed financial markets, where foreign investors can have greater experience valuing assets and therefore provide more reliable pricing information. Therefore, the impact of capital account liberalization on asset market liquidity and pricing efficiency must be resolved empirically. This is an important issue not only in and of itself, but also because stock market mispricing can affect a number of firm-level variables, such as the cost of debt, total investment, foreign direct investment and merger and acquisition activity. ${ }^{29}$

Li, Morck, Yang and Yeung (2004) is one study that provides evidence on how capital account liberalization could affect the efficiency of asset pricing. This study examines the extent to which individual stock prices move up and down together in specific countries—what is also called "synchronicity”. High levels of comovement and low levels of firm-specific variation in prices suggest that stock prices are less efficient. In other words, when stock prices are driven more by aggregate, country-level news instead of by firm-specific variables and information, there is less market discipline. This paper uses several different measures to show that greater openness in capital markets (but not in goods markets) is correlated with a greater firm-specific content in stock prices. Therefore, greater openness in capital markets is associated with more market discipline and more efficient stock market pricing. This relationship is magnified in countries with strong institutions and good governance.

One set of results in the working paper version of Li, Morck, Yang and Yeung (2004) is particularly relevant to the previous discussion of the impact of the Asian crisis and

\footnotetext{
${ }^{29}$ Different studies in this literature find different effects. See Baker, Foley and Wurgler (2004) for an overview.
} 
Malaysian capital controls on stock market prices. ${ }^{30}$ Around the time of the Asian crisis, the firm-specific variation in stock prices increased significantly in most Asian countries and remained high for an extended period. This pattern is graphed for Korea in Figure 4, and is typical of most open economies in the region. In Malaysia, the firm-specific component of stock prices also increased significantly after the Asian crisis, but then fell sharply after capital controls were imposed (as also shown on Figure 4). Although not a definitive test, this comparison supports the claim that the Asian crisis increased market discipline and the firm-specific content in stock prices, while the Malaysian capital controls suppressed market discipline and reduced the efficiency of stock market prices.

Several studies have focused on an even narrower aspect of the relationship between capital controls and asset pricing by examining the impact of firms "migrating” abroad (i.e., of cross-listing on foreign stock markets, issuing depositary receipts, or raising capital directly in international markets). Capital controls can limit—or even restrict entirely - the ability of firms to access international capital markets through these channels. An extensive literature evaluates the impact of migration on firms that access international markets, as well as the corresponding impact on domestic firms that do not migrate. Bekaert and Harvey (2003) includes a summary of this literature. Firms which access international capital markets generally attain a lower cost of capital and greater trading liquidity. Levine and Schmukler (2004), however, show that migration reduces the trading activity and liquidity of domestic firms that do not raise capital internationally. Migration not only shifts some trading activity abroad, but also shifts trading activity within the domestic market away from purely domestic firms to the “migrated” firms.

\section{Summary}

This series of cross-country and case studies on the impact of capital controls, capital account liberalization, and broader financial market development on market discipline and the allocation of capital provides several insights. First, capital controls can reduce

\footnotetext{
${ }^{30}$ These results were removed from the published version of the paper but are included in the working paper version prepared for the conference on Global Linkages held at the IMF on January 30-31, 2003. The paper is available at: http://web.mit.edu/kjforbes/www/GL-Website/GL-Conference.htm
} 
market discipline and insulate the economy from competitive forces. Second and closely

related, financial development, and especially capital market liberalization, lead to a more efficient allocation of capital across firms. Third, these effects of capital controls work through a number of different channels—including effects on stock market valuations, access to financing, the government's ability to channel resources inefficiently, and the efficiency of stock market pricing. Therefore, capital controls appear to have widespread effects on market discipline and the allocation of capital across firms, effects that are likely to reduce productivity and growth.

\section{Capital Controls and the Behavior of Firms and Individuals}

Capital controls can cause firms and individuals to alter their behavior to minimize the costs created by the controls. This modification in behavior can result from the explicit tax imposed by the capital controls, as well as from the impact of capital controls on the supply and allocation of capital. In some cases, this modification of behavior can involve inaccurate or dishonest reporting or accounting in order to evade the controls outright. These types of attempts by firms and individuals to minimize the costs of capital controls can create additional distortions in an economy.

\section{A. Capital Controls and Firm Behavior}

One careful study of how capital controls affect firm behavior focuses on U.S. multinationals. Desai, Foley and Hines (2004) shows that U.S. multinationals adjust their trade patterns, profits and dividend repatriations in order to evade capital controls in other countries. For example, the study estimates that multinational affiliates are about $10 \%$ more likely to remit dividends to parent companies in the presence of capital controls, and that the distortions to profitability from capital controls are comparable to a $24 \%$ increase in the corporate tax rate. It also shows that the cost of borrowing is higher in countries with capital controls, and when this effect is combined with the other steps multinationals take to evade the controls, this reduces the size of foreign investment by multinationals by $13 \%$ to $16 \%$. Therefore, capital controls can not only create widespread 
distortions to how foreign companies behave in countries with controls, but they also reduce the total amount of foreign direct investment available to host countries.

Another study that examines the effect of capital controls on firm behavior focuses on local firms instead of multinational affiliates. Schmukler and Vesperoni (2001) uses firmlevel data from East Asia and Latin America for the 1980's and 1990's to examine how leverage ratios, debt maturity structures, and financing sources change when countries increase their integration with international equity and bond markets and undergo financial liberalization. The study finds that, on average, debt maturity tends to shorten but debt-equity ratios do not increase. It also finds that domestic firms that participate in international markets obtain better financing opportunities and extend their debt maturities. Also, firms in economies with more developed domestic financial systems are less affected by liberalization. These results suggest that some, although not all, firms may have expanded financing opportunities when countries lift their capital controls and increase their integration with global financial markets.

Instead of focusing on a cross-section of countries, several studies examine how capital controls affect firm behavior in an individual country. Forbes (2003) shows that the encaje (the Chilean tax on capital inflows discussed in Section III) caused companies to adjust their financial structure in a number of ways. For example, immediately after the encaje was enacted, there was a sharp increase in the number of firms choosing to issue stock that could then be cross-listed in the United States as American Depositary Receipts (ADRs). Individuals trading stock listed as secondary ADRs could avoid paying the encaje. In 1995, however, the Chilean government closed this loophole and included ADRs under the encaje. The number of Chilean firms issuing stock plummeted. Figure 5 shows these distortions to Chilean stock listings created by the encaje and changes in its coverage. Cifuentes, Desormeaux, and González (2002) also discusses how changes in this ADR loophole affected the evolution of the Chilean stock market. This paper argues that the extension of the encaje to include secondary ADRs significantly reduced financial liquidity, transactions, and investment in the domestic stock market-a reduction which persisted even after the encaje was lifted. 
Gallego and Hernández (2003) performs an even more detailed empirical analysis of how the encaje affected the financial decisions of Chilean firms. The study finds that the encaje caused firms to reduce their leverage ratios and paid capital, and increase their reliance on retained earnings. This suggests that the capital controls raised the cost of borrowing and of issuing equity, although the average magnitudes of these effects were fairly small. The study also finds that the encaje shortened the maturity of debt, while reducing the relative importance of short-term financial debt, indicating that firms shifted to other sources of short-term funding to avoid the tax (such as delaying tax payments and obtaining credit from suppliers). Moreover, one fairly consistent finding throughout the study is that estimates of the average effects of the capital controls mask significant differences across firms (as was found in the work discussed in Section III on the impact of the encaje on firm-financing constraints). Firms that were larger, belonged to a conglomerate, or were able to issue securities abroad were more likely to respond to the capital controls by reducing their leverage through increases in their capital base (instead of resorting to retained earnings). Other firms, and especially smaller firms, were more likely to respond to the capital controls by resorting to retained earnings for financing and increasing their reliance on short-term debt.

Other than the cross-country and Chilean studies on how capital controls affect firm behavior, most other evidence relies on anecdotes instead of formal empirical analysis. Several of these case studies, however, provide more concise descriptions of exactly how companies adapt their behavior in order to avoid capital controls. Many of these mechanisms are difficult to test empirically_-but they could explain some of the more general effects discussed throughout this paper. One such study by Loungani and Mauro (2001) focuses on Russia. ${ }^{31}$ This paper provides a detailed description of different strategies followed by Russian firms to evade capital controls. For example, in order to take money out of the country, firms would overstate import payments, including the use of fake import contracts for goods and services. Companies would also create enterprises

\footnotetext{
${ }^{31}$ Also see Tikhomirov (1997) for an excellent description of different methods used to evade capital controls in Russia.
} 
with the sole purpose of presenting fake import contracts requiring advance payments, and then the enterprises would be dissolved once the funds had been transferred out of the country. Companies would also misrepresent export earnings, such as by underinvoicing exports or exporting via an offshore subsidiary with a low recorded transfer price (so that the margin between the transfer and market prices could be deposited offshore). All Russian firms, however, were not equally adept at circumventing the controls, contributing to uneven competitive conditions and distorting the allocation of resources. The study presents evidence that firms' ability to evade the capital controls was widespread and that, as a result, capital controls increased corruption and lowered economic efficiency in Russia.

\section{B. Capital Controls and Individual Behavior}

Individuals, as well as firms, can modify their behavior to minimize the cost of capital controls - or even evade them outright. One compelling example is how individuals responded to the "corralito" enacted by Argentina at the end of 2001. The corralito restricted capital outflows and withdrawals from the banking system. During this period the stock market rose dramatically, despite a sharp economic contraction, a plummeting peso, and a banking system on the verge of collapse. Auguste, Dominguez, Kamil and Tesar (2002) explains this apparent discrepancy. Investors dodged the capital controls by purchasing Argentine stocks for pesos, converting the stocks into ADRs, and then selling the ADRs in New York for dollars that could be deposited in U.S. bank accounts. The study estimates that the capital outflow through this single loophole was between $\$ 835$ million and \$3.4 billion in just the four months staring in December 2001. Investors were willing to pay a substantial premium to evade the corralito - with some ADRs trading at a discount of over $40 \%$. Once the conversion of Argentine shares into ADRs was prohibited, the premium returned to nearly zero. Figure 6 (replicated from the paper) shows these trends for one Argentine stock. Melvin (2003) also studies the same episode and reaches similar conclusions. The surge in the ADR premium during the period of the corralito reflects what investors were willing to pay to avoid the Argentine capital controls. 
Several papers also describe how investors adjusted their behavior to avoid capital controls in Russia. For example, Tikhomirov (1997) provides a number of examplesincluding how Russian citizens would hold foreign currency funds in banks abroad so that they could invest and utilize these resources more freely. Abalkin and Whalley (1999) discuss how Russian citizens would convert local currency holdings and bank deposits into dollars, partially to facilitate evasion of the controls.

\section{Summary}

This series of microeconomic studies suggests that capital controls can cause widespread distortions in the behavior of firms and individuals. U.S. multinationals adjust their trade patterns, profits and dividend repatriations to evade the controls. Domestic companies adjust their debt maturities and financing structures when capital controls are lifted. Individuals are willing to pay a substantial premium for a financial transaction that allows them to evade controls. Companies and individuals adopt numerous accounting gimmicks -including creating temporary corporations-simply to dodge the controls. These widespread distortions to firm and individual behavior resulting from the capital controls are likely to be inefficient.

\section{The Enforcement of Capital Controls}

Since firms and individuals will respond to capital controls by adjusting their behavior, enforcing the controls and ensuring they are effective can not only be a challenge, but also involve substantial administrative costs. Implementing capital controls is often a dynamic process. After a system of controls is specified, firms and individuals often find ways to evade the controls, diminishing their effectiveness over time. Governments that do not wish to see the effectiveness of the controls weakened will need to constantly adopt new controls and regulations in order to close loopholes and respond to the adjustments in behavior that resulted from the initial controls. Countries with weak institutions, especially a weak rule-of-law and high levels of corruption, are even less likely to be able to implement and enforce capital controls. Moreover, by providing an 
opportunity for government officials to collect rents, capital controls can increase incentives for corruption and undermine institutions.

There is extensive anecdotal evidence from different countries on the difficulty faced by governments attempting to enforce capital controls and the link between capital controls and corruption. For example, Tikhomirov (1997) provides a fairly detailed account of the attempts by the Russian government to limit illegal capital flight. Despite continually passing new rules and regulations in order to improve the government's control over capital flows, many of these rules were highly ineffective and capital flight was extensive. Different sources suggest that capital flight from Russia between 1990 and 1995 was somewhere in the very wide range of $\$ 35$ billion to $\$ 400$ billion. The study asserts that: “...instead of cutting profits from the illegal transfer of foreign currency funds abroad, these measures [the controls] spread the corruption from the foreign trade sector to the bureaucracy and, later, to the banking sector.”32 Russia’s challenges in enforcing capital controls however, could partially result from the weak institutions in the country during the period of this study.

The Chilean experience with the encaje (discussed above) therefore provides a useful contrast. Chile has sound institutions, a strong rule-of-law, and low levels of corruption. Despite these advantages, the government was constantly modifying the encaje in order to close new loopholes that were discovered by firms and investors. These changes included everything from the types of inflows covered, to the currency with which to pay the tax, to restrictions on rolling-over maturing investments. ${ }^{33}$ Moreover, despite Chile's constant attempts to raise the amount of the tax, tighten the capital controls, and close loopholes, there is some evidence that the effectiveness of the controls may still have declined over time. ${ }^{34}$ Central bank data show that in 1992 the encaje covered about half

\footnotetext{
32 Tikhomirov (1997), pg. 595.

33 See Simone and Sorsa (1999) or Ariyoshi et al. (2000) for detailed information on this evolution of capital account restrictions in Chile over the 1990s.

${ }^{34}$ For example, Cowan and de Gregorio (1998) calculate the “power” of the controls and argue that their power declined between 1995 and 1997 as evasion increased. Other studies, however, argue that the power of the controls increased steadily over time until they were removed in 1998. For example, see Gallego, Hernández, and Schmidt-Hebbel (1999) and Valdés-Prieto and Soto (1998). Also see Simone and Sorsa (1999) for an overview of work on the evasion of the encaje.
} 
of total gross capital inflows, but in subsequent years coverage declined to only $24 \%$ of inflows. ${ }^{35}$ Despite these challenges enforcing the capital controls, however, the Chilean government still collected substantial revenues under the tax, suggesting that it still maintained some degree of effectiveness. ${ }^{36}$

Moreover, as new financial instruments continue to be developed and investors and firms become more adept at transferring capital across borders, it will become even more difficult to enforce capital controls. The recent case of Argentine investors using ADRs to evade the corralito provides a clear example of this challenge. After studying this experience, Auguste, Dominguez, Kamil and Tesar (2002) suggests that once countries allow financial market development, "it may be difficult if not impossible to reverse the process of capital market integration with (even draconian) capital controls." ${ }^{\text {,37 }}$

\section{Conclusions}

Although the cross-country macroeconomic evidence on how capital account liberalization affects growth has yielded mixed results, to date, a series of microeconomic papers provides far more persuasive evidence on the diverse effects of capital controls and capital account liberalization. The studies surveyed in this paper present compelling empirical evidence that capital controls can affect the supply and cost of capital, market discipline, the allocation of resources, and the behavior of firms and individuals. Several studies also find that the effects of capital account liberalization vary across types of firms, reflecting different pre-existing distortions under capital controls. For example, although lifting capital controls tends to reduce financial constraints for most firms, it can have no effect (or even increase financial constraints) for firms that received preferential treatment under the controls or had already found ways to evade them.

This microeconomic research on the impact of capital controls, however, is only in its

\footnotetext{
${ }^{35}$ Gallego, Hernández, and Schmidt-Hebbel (1999).

${ }^{36}$ Gallego, Hernández, and Schmidt-Hebbel (1999) report that between June 1991 and September 1998, the encaje increased central bank reserves by an average of $2.0 \%$ of GDP, or $40 \%$ of the average capital account surplus.

${ }^{37}$ Auguste, Dominguez, Kamil and Tesar (2002), pg. 4.
} 
infancy. Much more careful analysis is needed to better understand why capital account liberalization can have varied effects in different countries, and especially on what variables determine the success of liberalizations. For example, what are the microeconomic consequences of different sequencing when lifting capital controls? What are the microeconomic linkages between trade liberalizations and capital account liberalizations? How do different institutions interact with the microeconomic effects of capital controls? And are the benefits of capital account liberalization usually level effects or growth effects?

Moreover, although this paper discusses how capital controls and financial liberalizations directly affect a series of microeconomic variables, it does not address a number of additional channels by which capital controls could affect key macroeconomic variables (such as exchange rates, the financial system, and/or monetary policy), which could, in turn, have additional effects on firms and individuals. For example, controls on capital outflows could reduce pressure on a currency to depreciate, and controls on capital inflows could reduce pressure on a currency to appreciate. Controls on capital outflows could help support a weak financial system, while controls on capital inflows could hinder the development of a deeper and more efficient financial market. Controls on capital inflows and outflows could create a wedge between domestic and foreign interest rates, thereby providing a country with more flexibility to follow an independent monetary policy. Changes in exchange rates, the financial system, and interest rates will, in turn, affect a range of microeconomic variables in the economy. ${ }^{38}$ The paper also does not make any attempt to address the political economy of capital controls, such as analyzing what factors determine whether a country is more likely to adopt controls or liberalize its capital account. ${ }^{39}$

Although this survey does not address a number of questions, largely due to the limited microeconomic evidence that currently exists on these issues, it does present a series of convincing results on the effects of capital controls and benefits from capital account

\footnotetext{
${ }^{38}$ For example, see Forbes (2002a, b) for a literature review and analysis of just the single topic of how depreciations affect different measures of firm performance.

${ }^{39}$ For a discussion of these political economy questions, see Johnston and Tamirisa (1998).
} 
liberalizations. Although some specific effects vary across country experiences, capital controls generally reduce the supply of capital, increase the price of capital, and increase financial constraints, especially for smaller firms, firms in less distorted financial markets, and firms without access to international financial markets or preferred access to credit. Capital controls can insulate an economy from competitive forces, reducing market discipline and hindering the efficient allocation of capital through several channels. Capital controls can also cause widespread distortions in behavior, affecting multinationals, domestic companies and individuals. Moreover, administering capital controls requires a recurrent cost by the government, especially to enforce the regulations and update rules to close loopholes. These widespread effects of capital controls suggest that even though they may yield limited benefits in certain circumstances, they also have substantial and often unexpected economic costs. Capital controls are no free lunch. 


\section{References}

Abalkin, A. and John Whalley (1999). "The Problem of Capital Flight from Russia.” The World Economy 22(3, May): 412-44.

Abiad, Abdul, Nienke Oomes, and Kenichi Ueda (2004). “The Quality Effect: Does Financial Liberalization Improve the Allocation of Capital?” IMF Working Paper $\mathrm{WP} / 04 / 112$.

Aghion, Philippe, Philippe Bachetta, and Abhijit Banerjee (2001). "Currency Crises and Monetary Policy in an Economy with Credit Constraints." European Economic Review 45: 1121-50.

Ariyoshi, Akira, Karl Habermeier, Bernard Laurens, Inci Otker-Robe, Jorge Iván Canales-Kriljenko and Andrei Kirilenko (2000). "Capital Controls: Country Experiences with Their Use and Liberalization.” IMF Occasional Paper \#190.

Auguste, Sebastian, Kathryn Dominguez, Herman Kamil, and Linda Tesar (2002). "Cross-Border Trading as a Mechanism for Capital Flight: ADRs and the Argentine Crisis.” NBER Working Paper \# 9343.

Baker, Malcolm, C. Fritz Foley, and Jeffrey Wurgler (2004). “The Stock Market and Investment.” NBER Working Paper \#10559.

Bekaert, Geert and Campbell Harvey (2003). “Emerging Markets Finance.” Journal of Empirical Finance 10: 3-55.

Bekaert, Geert and Campbell Harvey (2000). "Foreign Speculators and Emerging Equity Markets.” Journal of Finance 55(2, April): 565-614.

Block, William and Kristin Forbes (2004). "Capital Flows to Emerging Markets: The Myths and Realities." Paper prepared for conference: "Myths and Realities of Globalization" at the Federal Reserve Bank of Dallas on November 4.

Chari, Anusha and Peter Blair Henry (2004a). "Is the Invisible Hand Discerning or Indiscriminate? Investment and Stock Prices in the Aftermath of Capital Account Liberalizations.” NBER Working Paper \#10318.

Chari, Anusha and Peter Blair Henry (2004b). "Risk Sharing and Asset Prices: Evidence from a Natural Experiment.” Journal of Finance 59(3, June): 1295-324.

Chinn, Menzie and Hiro Ito (2002). "Capital Account Liberalization, Institutions and Financial Development: Cross Country Evidence.” NBER Working Paper \#8967.

Cifuentes, Rodrigo, Jorge Desormeaux, and Claudio González (2002). "Capital Markets in the Chilean Economy: From Financial Repression to Financial Deepening.” Central Bank of Chile. Mimeo. 
Cowan, Kevin and José de Gregorio (1998). "Exchange Rate Policies and Capital Account Management: Chile in the 1990s.” In Reuven Glick, ed., Managing Capital Flows and Exchange Rates: Perspectives from the Pacific Basin. Cambridge University Press, pgs. 465-88.

Demirguc-Kunt, Asli and Vojislav Maksimovic (1998). "Law, Finance, and Firm Growth.” Journal of Finance 53(6): 2107-31.

Desai, Mihir, C. Fritz Foley, and James Hines (2004). "Capital Controls, Liberalizations, and Foreign Direct Investment.” NBER Working Paper \#10337.

Economist (2003). “A Slightly Circuitous Route.” May $1^{\text {st }}$.

Edison, Hali, Michael Klein, Luca Ricci, and Torsten Sloek (2002). "Capital Account Liberalization and Economic Performance: Survey and Synthesis.” NBER Working Paper \#9100.

Eichengreen, Barry (2003). Capital Flows and Crises. Cambridge, MA: The MIT Press.

Eichengreen, Barry (2001). "Capital Account Liberalization: What Do Cross-Country Studies Tell Us?” The World Bank Economic Review 15(3): 341-65.

Fischer, Stanley (2003). “Globalization and Its Challenges.” American Economic Review 93(2, May): 1-30.

Fischer, Stanley (2001). "Exchange Rate Regimes: Is the Bipolar View Correct?” Distinguished Lecture in Economics and Government. Delivered at the Meetings of the American Economic Association in New Orleans on January 6.

Forbes, Kristin (2003). "One Cost of the Chilean Capital Controls: Increased Financial Constraints for Smaller Traded Firms.” NBER Working Paper \#9777.

Forbes, Kristin (2002a). "Cheap Labor Meets Costly Capital: The Impact of Devaluations on Commodity Firms.” Journal of Development Economics 69(2, December): 335-65.

Forbes, Kristin (2002b). “How Do Large Depreciations Affect Firm Performance?” IMF Staff Papers 49: 214-38.

Galindo, Arturo, Fabio Schiantarelli, and Andrew Weiss (2003). "Does Financial Liberalization Improve the Allocation of Investment? Micro Evidence from Developing Countries.” Inter-American Development Bank Mimeo.

Gallego, Francisco and Leonardo Hernández (2003). "Microeconomic Effects of Capital Controls: The Chilean Experience During the 1990s.” International Journal of Finance and Economics 8(3): 225-53. 
Gallego, Francisco, Leonardo Hernández, and Klaus Schmidt-Hebbel (1999). "Capital Controls in Chile: Effective? Efficient?” Central Bank of Chile Working Paper \#59.

Gallego, Francisco, and Norman Loayza (2000). "Financial Structure in Chile: Macroeconomic Developments and Microeconomic Effects.” Central Bank of Chile Working Paper \#75.

Gelos, R. Gaston and Alejandro Werner (2001). “Financial Liberalization, Credit Constraints, and Collateral: Investment in the Mexican Manufacturing Sector.” Journal of Development Economics 67(1): 1-27.

Gelos, Gaston and Shang-Jin Wei (2002). “Transparency and International Investor Behavior.” NBER Working Paper \#9260.

Harris, John, Fabio Schiantarelli, and Miranda Siregar (1994). “The Effect of Financial Liberalization on the Capital Structure and Investment Decisions of Indonesian Manufacturing Establishments.” World Bank Economic Review 8(1): 17-47.

Harrison, Ann, Inessa Love, and Margaret McMillan (2004). "Global Capital Flows and Financing Constraints.” Journal of Development Economics 75(1): 269-301.

Henry, Peter (2000). “Do Stock Market Liberalizations Cause Investment Booms?” Journal of Financial Economics 58(October): 301-34.

Henry, Peter and Peter Lorentzen (2003). "Domestic Capital Market Reform and Access to Global Finance: Making Markets Work.” NBER Working Paper \#10064.

Jaramillo, Fidel, Fabio Schiantarelli, and Andrew Weiss (1996). “Capital Market Imperfections Before and After Financial Liberalization: An Euler Equation Approach to Panel Data for Ecuadorian Firms.” Journal of Development Economics 51(2): 367-86.

Jaramillo, Fidel, Fabio Schiantarelli, and Andrew Weiss (1992). “The Effect of Financial Liberalization on the Allocation of Credit: Panel Data Evidence for Ecuador.” World Bank Policy Research Department Working Paper \#WPS 1092.

Johnson, Simon and Todd Mitton (2002). “Cronyism and Capital Controls: Evidence From Malaysia.” Journal of Financial Economics 67: 351-82.

Johnston, R. Barry, and Natalia Tamirisa (1998). "Why Do Countries Use Capital Controls?” IMF Working Paper WP/98/181.

Klein, Michael and Giovanni Olivei (1999). “Capital Account Liberalization, Financial Depth and Economic Growth.” NBER Working Paper \#7384. 
Laeven, Luc (2003). “Does Financial Liberalization Reduce Financing Constraints?”

Financial Management Spring: 5-34.

Levine, Ross (2004). “Finance and Growth: Theory and Evidence.” NBER Working Paper \#10766.

Levine, Ross and Sergio Schmukler (2004). "Migration, Spillovers, and Trade Diversion: The Impact of Internationalization on Domestic Stock Market Activity.” Unpublished mimeo, April 28.

Li, Kan, Randall Morck, Fan Yang, and Bernard Yeung (2003). "Firm-Specific Variation and Openness in Emerging Markets.” Review of Economics and Statistics 86(3, August): 658-69.

Loungani, Prakash and Paolo Mauro (2001). “Capital Flight From Russia.” The World Economy 24(5, May): 689-706.

Love, Inessa. (2003). "Financial Development and Financing Constraints: International Evidence from the Structural Investment Model.” Review of Financial Studies 16(3, Fall): 765-91.

Lucas, Robert (1990). "Why Doesn't Capital Flow from Rich to Poor Countries?" American Economic Review, Papers and Proceedings 80(May): 92-6.

Magud, Nicolas and Carmen Reinhart (2004). "Controls on International Borrowing: An Evaluation of Alternative Measures Used to Restrict Capital Inflows”. Paper presented at NBER Conference on International Capital Flows held in Santa Barbara, CA on $12 / 17 / 04$.

Melvin, Michael (2003). “A Stock Market Boom during a Financial Crisis? ADRs and Capital Outflows in Argentina.” Economic Letters 81:129-36.

Prasad, Eswar, Kenneth Rogoff, Shang-Jin Wei, and M. Ayhan Kose (2003). "Effects of Financial Globalization on Developing Countries: Some Empirical Evidence.”

International Monetary Fund Occasional Paper \#220.

Rajan, Raghuran and Luigi Zingales (1998). "Financial Dependence and Growth.” American Economic Review 88(3): 559-86.

Reisen, Helmut and Marcelo Soto (2001). "Which Types of Capital Inflows Foster Developing-Country Growth?” International Finance 4(Spring): 1-14.

Rogoff, Kenneth and Carmen Reinhart (2004) "Serial Default and the 'Paradox' of Rich to Poor Capital Flows.” NBER Working Paper \#10296. 
Rossi, Marco (1999). "Financial Fragility an Economic Performance in Developing Economies: Do Capital Controls, Prudential Regulation and Supervision Matter?” IMF Working Paper \#99/66.

Rubin, Robert and Jacob Weisberg (2003). In an Uncertain World: Tough Choices from Wall Street to Washington. New York: Random House.

Schmukler, Sergio and Esteban Vesperoni (2001). “Globalization and Firms’ Financing Choices: Evidence from Emerging Economies.” Unpublished working paper, World Bank.

Simone, Francisco Nadal De and Piritta Sorsa (1999). “A Review of Capital Account Restrictions in Chile in the 1990s.” IMF Working Paper \#99/52.

Tikhomirov, Vladimir (1997). "Capital Flight from Post-Soviet Russia,” Europe-Asia Studies 49(4, June): 591-616.

Valdés-Prieto, Salvador and Marcelo Soto (1998). “The Effectiveness of Capital Controls: Theory and Evidence from Chile.” Empirica 25(2): 133-64.

Wurgler, Jeffrey (2000). “Financial Markets and the Allocation of Capital.” Journal of Financial Economics 58(1): 187-214. 
Figure 1: Conditional Relationship Between Financial Openness and Growth

Growth rate of per capita GDP: 1982 - 1997

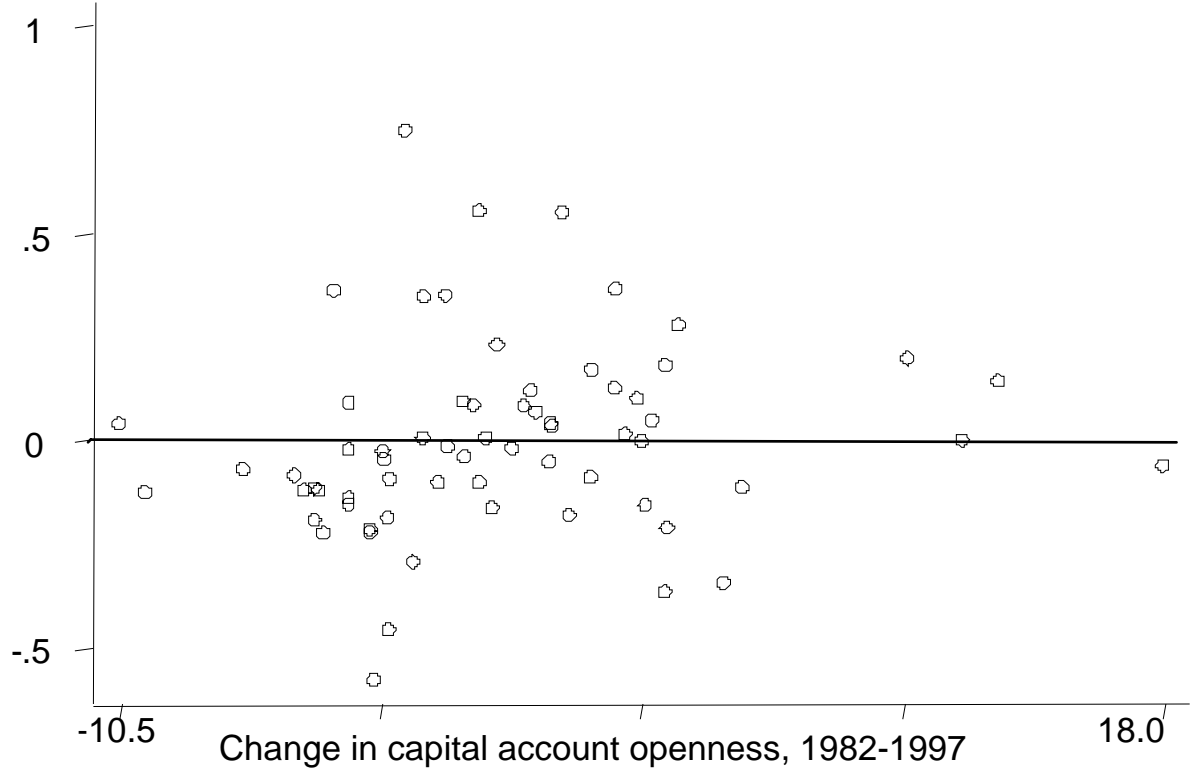

Notes: Growth is measured by growth in real per capita GDP. Conditioning variables are: initial income, initial schooling, average investment/GDP, political instability, and regional dummies

Source: Prasad, Rogoff, Wei and Kose (2003)

Figure 2: Net Capital Flows to Emerging Markets

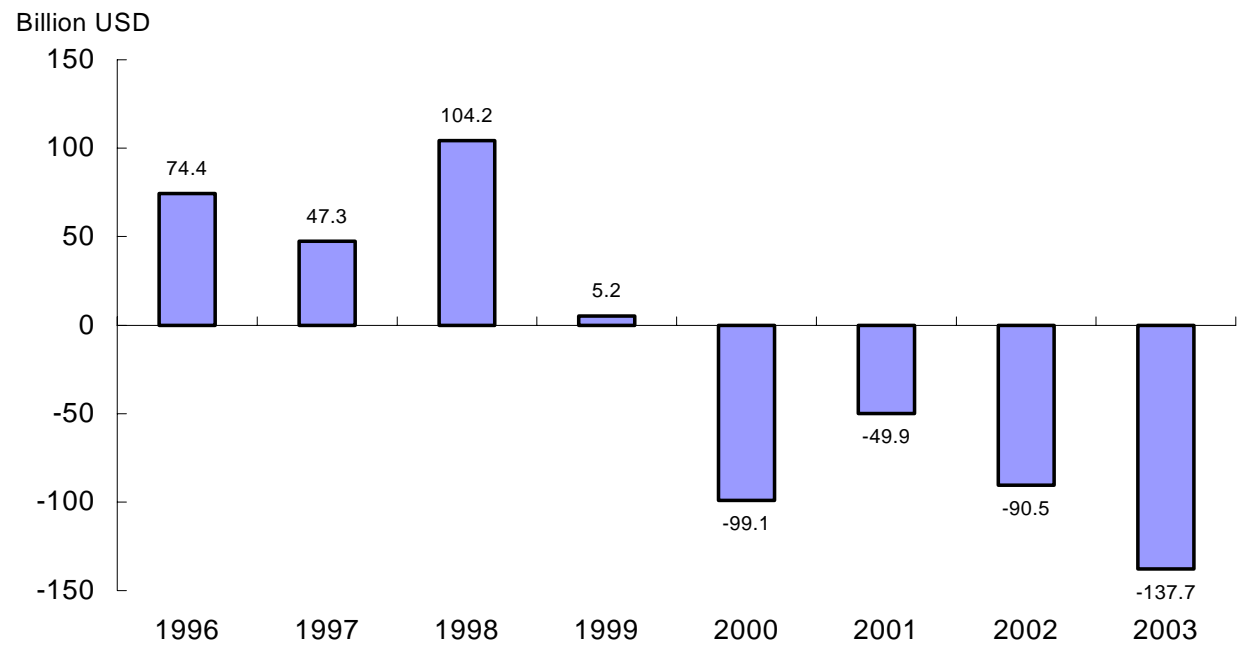

Note: Emerging market countries are those included in the EMBI and/or EMBI+.

Source: IMF Global Financial Stability Report. 
Figure 3: Growth in Investment / Capital Ratios for Chilean Firms

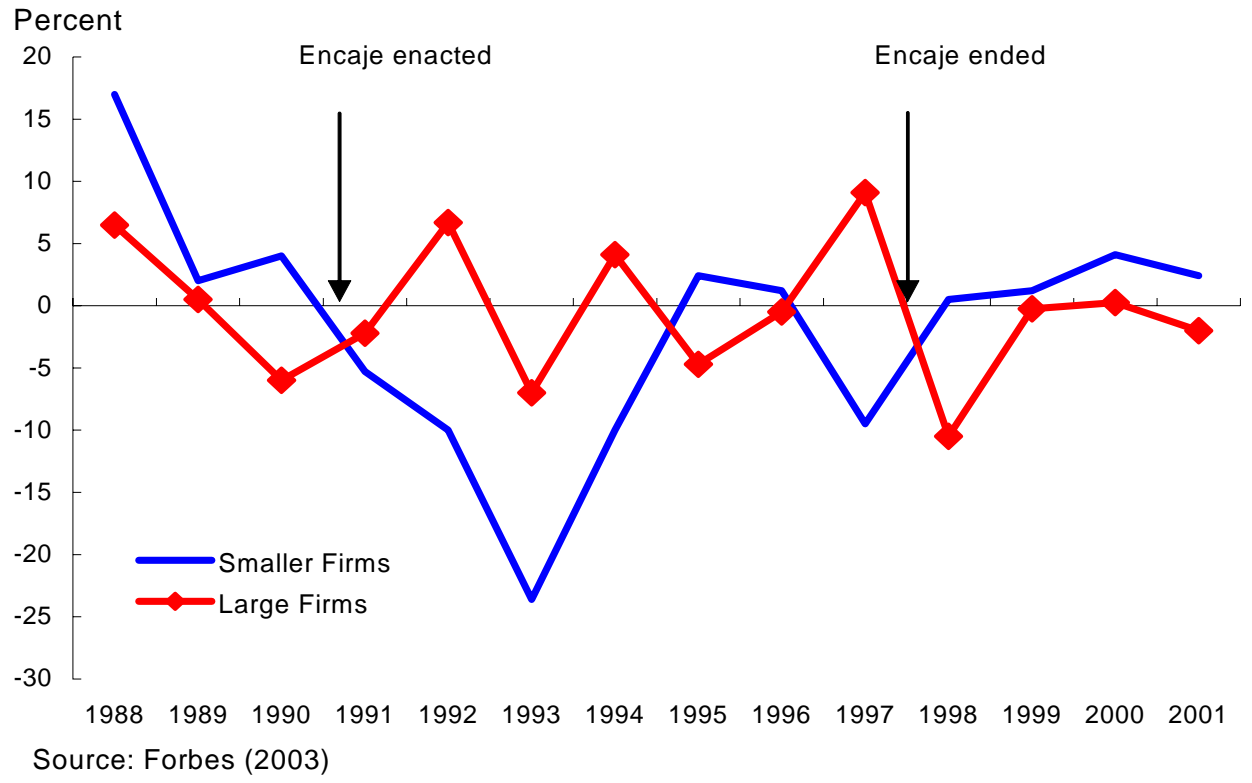

Figure 4: Firm-Specific Variation in Stock Prices

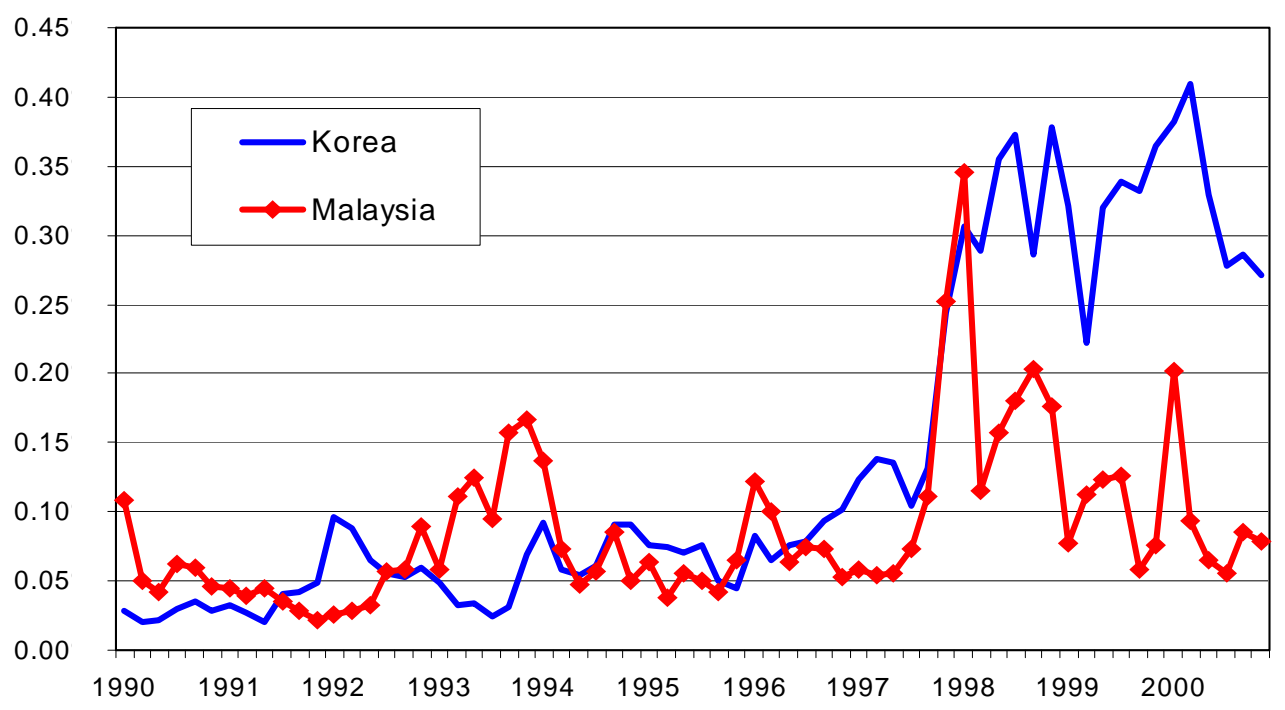

Note: Higher levels of firm-specific variation in stock prices indicate greater pricing efficiency. Source: Based on data from Li et al (2004). 


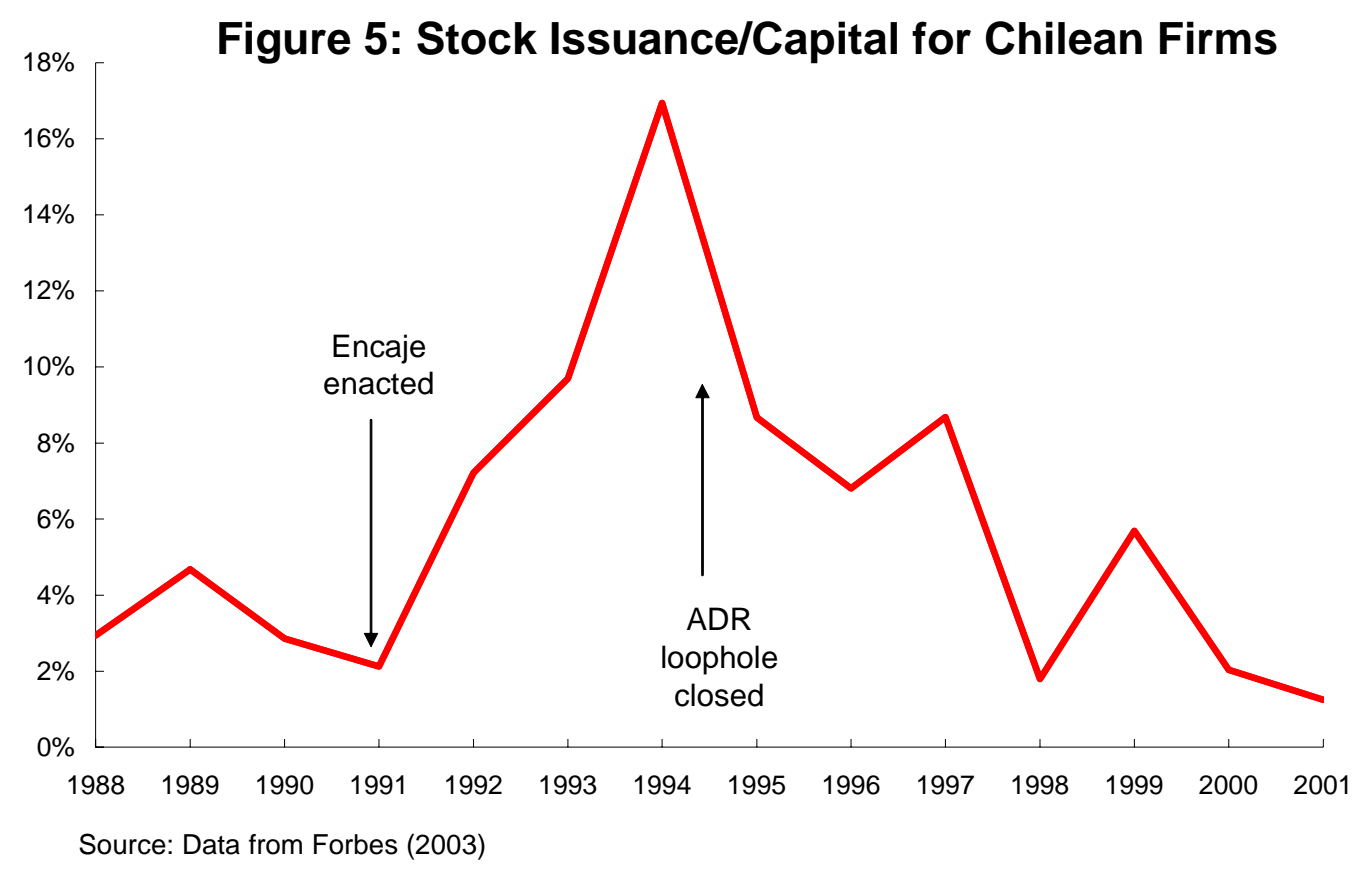

Figure 6: Argentine and U.S. Prices and Premia for Perez Companc LOCAL AND US PRICE IN \$US: PEREZ COMPANC

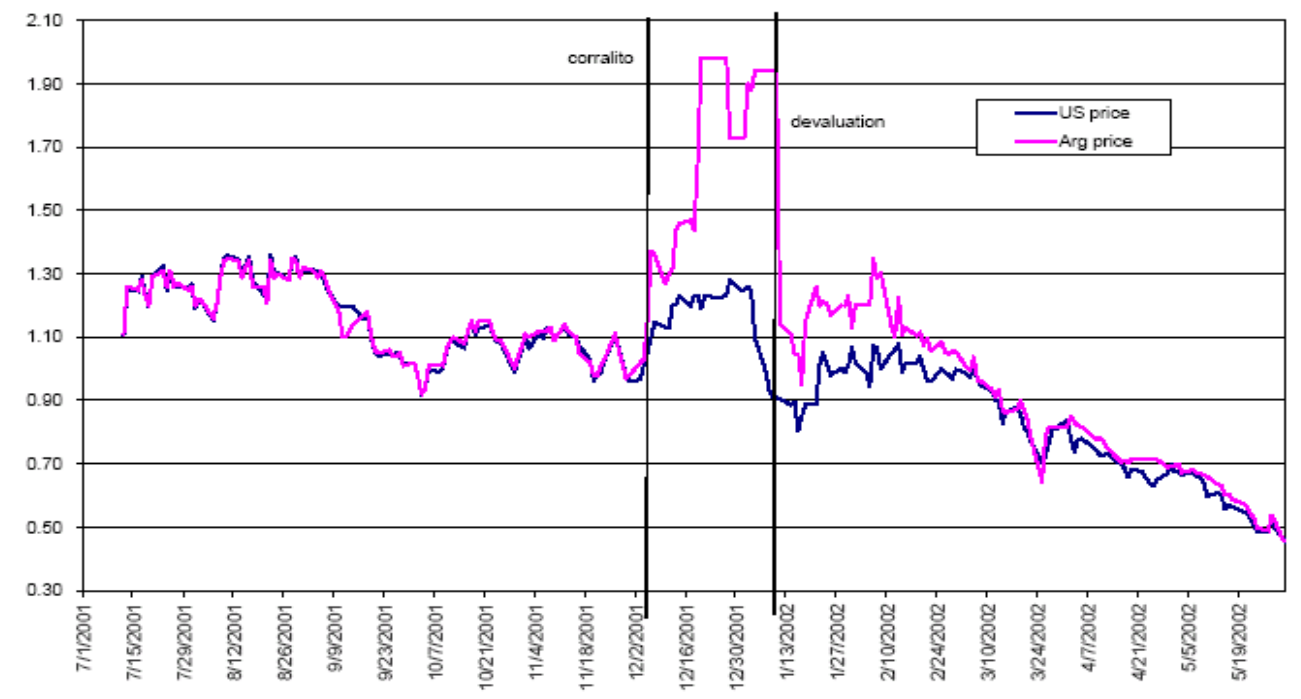

Source: Auguste, Dominguez, Kamil and Tesar (2002), Figure 6. 